\title{
Socio-Economic Impact of Non-Timber Forest Products in Income Generation for Sustainable Forest Management in Gambari Forest Reserve, Oyo State, Nigeria.
}

\author{
Odeyale Olajumoke Celinah \\ Department of Forestry Technology, Federal College of Forestry, Ibadan \\ Forestry Research Institute of Nigeria. \\ Ibadan, Oyo State, Nigeria. \\ Jumoceline81@gmail.com \\ Olawuyi, Eseoghene Bridget \\ Department of Forestry Technology, Federal College of Forestry, Ibadan \\ Forestry Research Institute of Nigeria. \\ Ibadan, Oyo State, Nigeria. \\ bridgetonyenue@yahoo.com
}

DOI: 10.31364/SCIRJ/v6.i10.2018.P1018573

http://dx.doi.org/10.31364/SCIRJ/v6.i10.2018.P1018573

\begin{abstract}
Non-timber forest products (NTFPs) are vital to world food security mostly because of the dependence of majority of people especially the forest rural poor on forest products for food, shelter and other basic necessities. However, the sustainable production of many NTFPs is no longer assured in many places in which it is used and managed. Therefore, this study assessed the socio-economic impact of non-timber forest products in income generation for sustainable forest management (SFM) in Gambari forest reserve, Oyo state. Twenty households were selected from three communities (Ibusogboro, Gambari and Onipe) out of a total of ten communities in the study area using the simple random sampling procedure. The main targets were the household heads. A total of sixty respondents were selected for the study. Both primary and secondary data was used for this study. Primary data was collected through the use of questionnaire while secondary data was obtained from literatures and internet. The questionnaire was designed to elicit information on the socio-economic characteristics of the respondents, income generating opportunities, NTFPs available in the study area and socioeconomic impact of income generating opportunities in enhancing rural livelihood. Data were subjected to descriptive statistics and logit regression. Result showed that majority of respondents is male with 61.7\%, age class of 31-40 years (50.0\%), married (56.7\%), (31.7\%)had no formal education, main occupation was farming (45.0\%) and 55.0\% have 11-15years experience in NTFPs business. most abundant NTFPs were fuel wood (63.3\%) and palm wine (43.3\%). 28.3\% of respondents generated income above N600,000/annum equivalent to US\$5.05 per day. Logistic regression indicated that high standard of living, high income (HI), basic health care (BHC), and provision of food (PF) was the most significant income generating opportunities with odds-ratio of 4.80,3.30, 3.02 and 2.64 respectively. NTFPs in income generation can only be effective for sustainable forest management if forest resources are effectively managed.
\end{abstract}

Keywords: Forest reserves, Income, Livelihood, NTFPs, Rural communities, Sustainable forest management. 


\section{Introduction}

The role of non-timber forest products (NTFPs) for sustainable forest management and poverty reduction has received increased attention for many years [3]. They play an important role in supporting household livelihoods and therefore can be used to raise the value of forest resources [11]. In Nigeria majority of rural households and a large proportion of urban households depend on NTFPs to meet some part of their nutritional health, construction materials and income generation for rural development, more equitable sharing of the benefits of forest and local participation in forest management [7].

In economic terms, NTFPs contributes substantially to national economic growth and international trade [17]; likewise, [19] reported that the NTFPs contributed around $68 \%$ of total monthly household income within Gambari forest reserve in Nigeria. [8]noted that rural women were found to be making $\$ 15,000 /$ month from fruits gathering and sales from the forest for their household sustainability. It is therefore paradoxical that in spite of their real and potential value, most NTFPs remained grouped as minor products of forest management and is neither conducive to sustainable management of the forests. Therefore, this study is aimed at assessing the socio-economic impact of non-timber forest products in income generation for sustainable forest management in Gambari forest reserve, Oyo state, Nigeria.

\section{The Study Area}

The study was carried out in Gambari Forest reserve; located between Latitudes $7^{0} 4^{\prime} \mathrm{N}$ and $7^{0} 14$ ' $\mathrm{N}$ and Longitudes $3^{0} 42^{\prime} \mathrm{E}$ and $3^{0} 56^{\prime} \mathrm{E}$ within the low land semi-deciduous rainfall belt of Nigeria and cover a total land area of 17,984ha. The topography of the study area is generally undulating, lying at an altitude between $90 \mathrm{~m}$ and $140 \mathrm{~m}$ above sea level. The annual rainfall ranges between $120 \mathrm{~mm}$ to $130 \mathrm{~mm}$ spreading over March to November. The dry season is severe and the relative humidity is low (about $42.3 \%$ ) and average annual temperature is about $2.64^{\circ} \mathrm{C}[18]$.

\section{Data collection and Analysis}

\section{Sampling procedure}

Simple random sampling was used to select three communities out of ten communities around the reserve namely; Ibusogboro, Gambari and Onipe. Twenty households were further selected randomly from each community making a total of sixty households. The main targets were the household heads. Therefore a total of sixty respondents were selected for the study. Both primary and secondary data was used for this study.Primary data was collected through the use of questionnaire while secondary data was obtained from literatures and internet. The questionnaire was designed to elicit information on the socio-economic characteristics of the respondents, income generating opportunities, NTFPs available in the study area and socio-economic impact of income generating opportunities in enhancing rural livelihood. Data were subjected to descriptive statisticsand logitregression.The binary logistic models are very useful in situations where the dependent or response variable is binary in nature. This implies that they can have only two possible values. The models therefore describe the relationship between one or more continuous independent variable(s) to the binary dependent variable. Distinctinformation provided by logit is the odds ratio. It is defined as the ratio of the odds of an event occurring in the group to the odds ratio of it occurringin another group [10]. Logit also provides information on the consequences of one variable on the other. Hence, it clearly indicates the income generating opportunities that is most effective in enhancing rural livelihood. The logistic model of a response $\mathrm{p}$ between 0 and 1 is given as: 
Logit $(p)=\log \left(\frac{p}{1-p}\right)=\log (p)-\log (1-p)$------------------ $($ Equation 3.3)

The simplest form of logistic model is expressed as:

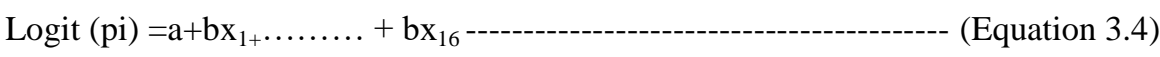

Where:

$\mathrm{P}^{\mathrm{i}}=$ Socio-economic impact of income generating opportunities in enhancing rural livelihood (SIGOERL)(Dependent variable)

$\mathrm{xi}=$ vector of predictor or independent variables

$\mathrm{a}$ and $\mathrm{b}=$ regression parameters

In binary choice models, the two possible results areassigned values of 1 or 0 . In this study, respondent that said yes to socioeconomic of income generating opportunities in enhancing rural livelihood was assigned avalue of 1 and respondent that said no to socio-economic impact of income generating opportunities in enhancing rural livelihood was assigned a value of 0 . Theparameter estimation for this study was done using Quasi-Newton method under logistic regression (logit)option of STATISTICA version 5 Software. Models tobe tested were obtained by fitting all the independentvariables together and backward, elimination was doneto obtain the best subset model. Emphasis was placedon keeping the model as simple as possible andselecting combinations of independent variables whichmake practical sense.In this study, the binary logistic regression analysiswas used to investigate the socio-economic impact of income generating opportunities in enhancing rural livelihood. The opportunities investigated were:High income (HI), High standard of living (HSL), Provision of food (PF), Provision of employment (PE), and Basic health care (BH). The resulting models were evaluated using thechi-square goodness-of-fit statistics [10;13]. TheFinal Loss on accuracy was computed using maximum likelihood estimation method and odds ratio [10].

\section{Results and Discussion}

Table 1: Socio-economic characteristic of respondents in the study area

\begin{tabular}{lll}
\hline Characteristics & Frequency & Percentage \\
\hline Sex & 37 & 61.7 \\
Male & 23 & 38.3 \\
Female & 60 & 100 \\
Total & & \\
Age & 1 & 1.7 \\
$<\mathbf{2 0}$ & 11 & 18.3 \\
$\mathbf{2 1 - 3 0}$ & 30 & 50.0 \\
$\mathbf{3 1 - 4 0}$ & 8 & 13.3 \\
$\mathbf{4 1 - 5 0}$ & 3 & 5.0 \\
$\mathbf{5 1 - 6 0}$ & 7 & 11.7 \\
$>\mathbf{6 0}$ & 60 & 100 \\
Total & & \\
Marital status & 15 & 25.0 \\
Single & 34 & 56.7 \\
Married & 6 & 10.0 \\
Widow & 5 & 8.3 \\
Divorced & 60 & 100 \\
Total & \multicolumn{2}{c}{ www.scirj.org } \\
& \multicolumn{2}{c}{ http://dx.doi.org/10.31364/SCIRJ/v6.i10.2018.P1018573 } \\
\hline
\end{tabular}




\begin{tabular}{lll}
\hline Educational status & & \\
No formal education & 11 & 31.7 \\
Primary & 16 & 26.7 \\
Secondary & 14 & 23.3 \\
Tertiary & 19 & 18.3 \\
Total & 60 & 100 \\
Occupation & & \\
Farmer & 27 & 45.0 \\
Artisan & 7 & 11.7 \\
Logger & 4 & 6.7 \\
NTFP collector & 12 & 20.0 \\
Trader & 10 & 16.7 \\
Total & 60 & 100 \\
\hline Source: Field survey, 2015 & &
\end{tabular}

Source: Field survey, 2015

Table 1 showed the socio-economic characteristics of respondents in the study area.The sex distribution of respondents in the study area showed that majority of respondents is male with $61.7 \%$ while the female respondents had a lower percentage of $38.3 \%$.This might be due to the fact that males are more energetic considering the tasking nature of the farming activities as a means of sustaining their families. This therefore supported the findings of [15], who stated that the males are more actively involved in farming than their female counterparts and also the findings of [12] stated that men generally have greater access to cash economy from farming activities. The result on age distribution of respondents revealed thatmajority (50.0\%) of the respondents in the study area fall within the age class of 31- 40 years. This was followed by those who are within the age class of 21-30 years with 18.3\%. However, the least age recorded in this study was those that fell below20 years of age with 1.7\%.This is an indication that most of the respondents are within the active age group. As well they are young, agile,full of vigour and strength to carry out the laborious activities involved in agricultural production/collection of NTFPs thereby raising income to sustain their daily needs.Marital status of respondents revealed that majority of respondents is married with $56.7 \%$ while the least number recorded are those respondents that are divorced with 8.3\%.The high percentage of the married may be due to the fact that majority of rural households practice polygamy. This therefore agreed with the findings of [14] who stated that majority of the married are mostly engaged in farming activities in the rural areas. With reference to educational level of respondents, it was revealed that majority (31.7\%) of respondents had no formal education. This was followed by those that had primary education with $26.7 \%$. However, those that had one form of tertiary education or the other recorded the least percentage with 18.3\%.It therefore supported the findings of [5] who reported that though education is an engine for development, it is not necessarily needed for the forest dependent communities as their utmost concern is the easy, cheap and readily available farm practice and NTFP gathering with which to generate income.It was also revealed that the main occupation of the respondents in the study area was farming which had the highest percentage of $45.0 \%$. This was followed by the non- timber forest products gathering with $20.0 \%$ while the least number or respondents were those who engaged in logging activities with 6.7\%.This implies that forest activities in the study area are propelled by majority of the farmers as they daily source for means of sustaining themselves, this corroborated the findings of [4] who reported that farming is the major economic activity in the rural areas.

Table 2: Respondents years of experience in NTFPs business in the study area

\begin{tabular}{lcc}
\hline Years of & Frequency & Percentage \\
business & & \\
\hline $\mathbf{0 - 5}$ & 11 & 18.3 \\
\hline
\end{tabular}




\begin{tabular}{lll}
\hline $\mathbf{6 - 1 0}$ & 16 & 26.7 \\
$\mathbf{1 1 - 1 5}$ & 33 & 55.0 \\
Total & 60 & 100 \\
\hline
\end{tabular}

Source: Field survey, 2015.

Table 2 showed the years of experience in NTFPs business. It was indicated that majority (55.0\%) of respondents had been in the business for 11-15years, while those with 0-5 years experience recorded the least percentage (18.3\%). This might be due to the great role played by NTFPs in meeting food and other basic needs of the rural populace. This therefore corroborated with the findings of [11] that rural populace depend on the NTFPs for a large number of their basic necessities of life.

Table 3: Available NTFPs in the study area

\begin{tabular}{|c|c|c|}
\hline Available NTFPs & Frequency & Percentage \\
\hline Fuel wood & $\begin{array}{cc}\text { Yes } & 38 \\
\text { No } & 22 \\
\text { Total } & \mathbf{6 0}\end{array}$ & $\begin{array}{c}63.3 \\
36.7 \\
\mathbf{1 0 0}\end{array}$ \\
\hline Fruit & $\begin{array}{lc}\text { Yes } & 17 \\
\text { No } & 43 \\
\text { Total } & \mathbf{6 0}\end{array}$ & $\begin{array}{l}28.3 \\
71.7 \\
\mathbf{1 0 0}\end{array}$ \\
\hline Mushroom & $\begin{array}{lc}\text { Yes } & 16 \\
\text { No } & 44 \\
\text { Total } & \mathbf{6 0}\end{array}$ & $\begin{array}{l}26.7 \\
73.3 \\
\mathbf{1 0 0}\end{array}$ \\
\hline Snail & $\begin{array}{lc}\text { Yes } & 9 \\
\text { No } & 51 \\
\text { Total } & \mathbf{6 0}\end{array}$ & $\begin{array}{l}15.0 \\
85.0 \\
100\end{array}$ \\
\hline Palm wine & $\begin{array}{lc}\text { Yes } & 26 \\
\text { No } & 34 \\
\text { Total } & \mathbf{6 0}\end{array}$ & $\begin{array}{l}43.3 \\
56.7 \\
\mathbf{1 0 0}\end{array}$ \\
\hline Sponge & $\begin{array}{lc}\text { Yes } & 12 \\
\text { No } & 48 \\
\text { Total } & \mathbf{6 0}\end{array}$ & $\begin{array}{l}20.0 \\
80.0 \\
\mathbf{1 0 0}\end{array}$ \\
\hline Honey & $\begin{array}{lr}\text { Yes } & 9 \\
\text { No } & 51 \\
\text { Total60 }\end{array}$ & $\begin{array}{l}15.0 \\
85.0 \\
100\end{array}$ \\
\hline Vegetable & $\begin{array}{l}\text { Yes } 18 \\
\text { No } \quad 42 \\
\text { Total } \quad \mathbf{6 0}\end{array}$ & $\begin{array}{l}30.0 \\
70.0 \\
\mathbf{1 0 0}\end{array}$ \\
\hline Wrapping leaf & $\begin{array}{lc}\text { Yes } & 19 \\
\text { No } & 41 \\
\text { Total } & \mathbf{6 0}\end{array}$ & $\begin{array}{l}31.7 \\
68.3 \\
\mathbf{1 0 0}\end{array}$ \\
\hline Shea butter & $\begin{array}{ll}\text { Yes } & 14 \\
\text { No } & 46 \\
\text { Total } & \mathbf{6 0}\end{array}$ & $\begin{array}{l}23.3 \\
76.7 \\
\mathbf{1 0 0}\end{array}$ \\
\hline Medicinal plants & $\begin{array}{lc}\text { Yes } & 8 \\
\text { No } & 52 \\
\text { Total } & \mathbf{6 0}\end{array}$ & $\begin{array}{r}13.3 \\
86.7 \\
\mathbf{1 0 0}\end{array}$ \\
\hline
\end{tabular}




\begin{tabular}{llc}
\hline Ropes & Yes 6 & 10.0 \\
& No 54 & 90.0 \\
& Total 60 & $\mathbf{1 0 0}$ \\
& Yes 5 & 8.3 \\
Gums & No 55 & 91.7 \\
& Total 60 & $\mathbf{1 0 0}$ \\
\hline
\end{tabular}

Source: Field survey, 2015.

Table 3 showed the NTFPs available in the study area. Fuel wood was the most abundant NTFPs with 63.3\%, followed by palm wine $(43.3 \%$ ) while the least was gum with $8.3 \%$. The high percentage recorded in fuel wood may be due to the fact that fuel wood was mostly collected and used by rural households as source of fuel energy and also for sale to generate income for their daily needs. This result corroborated the findings of [16], who reported that forest biomass has remained the most common source of household energy in Nigeria, meeting $80 \%$ of domestic energy requirements.

Table 4: Income generated ( $\$$ /annum from the sale of NTFPs in the study area

\begin{tabular}{lcc}
\hline Income generated $(\mathbf{N})$ & Frequency & Percentage \\
\hline $\mathbf{1 0 0 , 0 0 0 - 1 9 0 , 0 0 0}$ & 6 & 10.0 \\
$\mathbf{2 0 0 , 0 0 0 - 2 9 0 , 0 0 0}$ & 8 & 13.3 \\
$\mathbf{3 0 0 , 0 0 0 - 3 9 0 , 0 0 0}$ & 13 & 21.7 \\
$\mathbf{4 0 0 , 0 0 0 - 4 9 0 , 0 0 0}$ & 5 & 8.3 \\
$\mathbf{5 0 0 , 0 0 0 - 5 9 0 , 0 0 0}$ & 11 & 18.3 \\
Above 600,000 & 17 & 28.3 \\
Total & 60 & 100 \\
\hline
\end{tabular}

Source: Field survey, 2015.

Table 4 revealed income generated from NTFPs per annum by respondents in the study area. Majority (28.3\%) generated above $\$ 600,000 /$ annum while a few respondents $(8.3 \%)$ generated between $\$ 400,000$ - $\$ 490,000$.The amount generated from gazetted forest reserves in the study area was an indication that the respondents generated income from the sale of NTFPs to sustain their needs. However, if forest resources are sustainably and effectively managed it can serve as a sustainable means of income generation especially for forest dependent communities as well as its urban counterpart. This result therefore corroborated the findings of [6] who reported that forest resources do not only play a role in the subsistence economy, but also have the potential and real contribution to the economies of many developing countries and household food security and the findings of [2] that the forest also contribute to poverty alleviation through generation of income, providing food and improved nutrition, medicine and foreign exchange earnings.

Table 5: Computation of income (\$) generated per day by respondents in the study area.

\begin{tabular}{|c|c|c|c|c|}
\hline Amount (N) & Frequency & Percentage & $\begin{array}{l}\text { Amount (N) per } \\
\text { day }\end{array}$ & $\begin{array}{l}\text { Amount (US\$) } \\
\text { per day }\end{array}$ \\
\hline
\end{tabular}




\begin{tabular}{|c|c|c|c|c|}
\hline 100,000-190,000 & 6 & 10.0 & 397.26 & 1.13 \\
\hline 200,000-290,000 & 8 & 13.3 & 671.23 & 1.92 \\
\hline $300,000-390,000$ & 13 & 21.7 & 945.21 & 2.70 \\
\hline 400,000-490,000 & 5 & 8.3 & 1219.18 & 3.48 \\
\hline $500, \mathbf{0} 00-590,000$ & 11 & 18.3 & 1493.15 & 4.27 \\
\hline Above 600,000 & 17 & 28.3 & $<1767.12$ & $<5.05$ \\
\hline Total & 60 & 100 & - & - \\
\hline
\end{tabular}

\section{Source: Field survey, 2015,}

Table 5 showed the computation of income per day in naira and dollars generated by the respondents in the study area. Income generated per day in naira and dollars by majority of respondents (28.3\%) wasabove $\$ 1767.58$ which was equivalent to US\$5.05per day (where $\$ 350.00=$ US\$1). Judging from the findings of [20] majority of respondents can be categorized as living above the poverty level. This corroborated with the findings of [1] that rural households spend income generated from the sale of NTFPs to buy food to maintain their families.

\section{The binary regression model obtained for socio-economic impact of income generating opportunities in enhancing rural livelihood}

SIGOERL $_{(\text {Gambari forest reserves })}=1.74+1.37 \mathrm{HI}+1.69 \mathrm{HSL}+0.08 \mathrm{PF}+0.02 \mathrm{PE}+1.89 \mathrm{BH}$

$\mathrm{N}=60$, Final loss $=17.00, \mathrm{Chi}-$ square $(\mathrm{df}, 5)=10.92, \mathrm{p}=0.0128$

Odds - ratio (Unit change): Constant (5.00); HI (3.30); HSL (4.80); PF (2.64); PE (1.18); BHC (3.02).

The model 1 presented for socio-economic impact of income generating opportunities in enhancing rural livelihood gave an overall significant fit to the data judging from $\chi^{2}$ value that was significant at $\mathrm{p}<0.05$. However, high standard of living (HSL) was the most significant income generating opportunities with odds-ratio of 4.80, followed by high income (HI), basic health care (BHC), and provision of food (PF) with odds-ratio of 3.30, 3.02 and 2.64respectively (Table 6).The result obtained from the logistic regression analysis indicated that the parameters in the model were statistically significant. There was sufficient evidence that the estimated coefficients were not zero for independent variables. This implies that the regression parameters in the model were statistically significant. However, the higher the value of odds-ratio, the more likelihood the variable contributes to the socio-economic impact of income generating opportunities in enhancing rural livelihood study area. This implication was corroborated by [10;13] that the logistic model provides information on the consequences of one variable or the other.

Table 6:Logistic binary nature for socio-economic impact of income generating opportunities in enhancing rural livelihood in Gambari forest reserve

Dependent variable (SIGOERL) $=$ Socio-economic impact of income generating opportunities in enhancing rural livelihood $($ Yes $=1$; No $=0$ ) 


\begin{tabular}{lcc}
\hline High income (HI) & 1.37 & $3.30^{*}$ \\
High standard of living (HSL), & 1.69 & $4.80^{*}$ \\
Provision of food (PF), & 0.08 & $2.64^{*}$ \\
Provision of employment (PE), & 0.02 & 1.18 \\
Basic health care (BHC). & 1.89 & $3.02^{*}$ \\
Model $\boldsymbol{X}^{\mathbf{2}}(\mathbf{d f}=\mathbf{5})$ & & \\
\hline
\end{tabular}

$*=$ significant at $\mathrm{p}<0.05$

\section{Conclusion}

The study which focusedon the socio-economic impact of income generating opportunities in enhancing rural livelihood revealed that majority of the respondents in the study area were males, age between 31-40years while 60 years and above were minority. However, the married had the highest percentage with majority having no formal education. Farming and forest product gathering were the major occupations in the reserve. The study also showed that the most available NTFPs in the study area were fuel wood and palm wine. Income generated from these NTFPs was above $\$ 6000$ /annum. In addition, high standard of living (HSL) was the most significant income generating opportunities followed by high income (HI), basic health care (BHC), and provision of food (PF) indicating that income generating opportunities has a great socio-economic impact in enhancing the livelihood of rural dwellers in the study area. Therefore, these income opportunities can only be effective for sustainable forest management if forest resources are effectively managed as a means of sustainable livelihood for forest dependent communities in the study area.

\section{References}

[1] A. Kugonza, M. Buyinza, and P. Byakagaba. Linking Local Communities Livelihoods and Forest Conservation in Masindi District, North Western Uganda.Research Journal of Applied Sciences, 2009 Volume 4, Issue: 10-16, DOI: 10.3923/rjasci.2009.10.16

[2] B.N Chikamai, and J. Kagombe. Country report for Kenya. In: Review and Synthesis on the State of Knowledge of Boswellia Spp. and Commercialisation of Frankincense in the Dry Lands of Eastern Africa. KEFRI, Nairobi. Pp12- 40. 2002

[3] D. Sheil and K. Wunder 2002. The Value of Tropical Forests to Local Communities: Complications, caveats and Cautions. Conservation Ecology, 6:2-9.

[4] E.E Ekong. An Introduction to Rural Sociology: An Introduction and Analysis of Rural Nigeria. Second edition. Dove Educational Publishers, Uyo, Nigeria pp 2. 2003

[5] F. Awe, C. O. Osadebe, E. Imoagene, A. Y. Fashina, T. S.Eniola, and E. O Adeleke. Assessment of Rural Households' Objectives for GatheringNon Timber Forest Products in Kogi State, Nigeria. Full Length Research Paper: African Journal of Environmental Science and technology. Vol 5(2), pp143-148.2011. http://academicjournals.org. Retrieved 20/9/15.

[6] FAO. Non- Wood Forest Products in Nutrition.Food and Nutrition Division. In Non-wood forest products for sustainable forestry. Yogyakarta, Indonesia, 17-27 January 2006. Non-wood Forest Products, FAO. Rome. Pp34. 2006a

[7] FAO. Resources Assessment of Non-Wood Forest Products: Experience and Biometric Principles (eds, Jennifer LG, Kirsti T and Nell B). FAO, Rome 2001.109Pp

[8] G. J Osemeobo. Effect of Common Property Resources Utilization on Wildlife Conservation in Nigeria. Geojournal 23:241-248. 1991. 
[9] H.T.O Davies, I.K Crombie, and M. Tavakoli. When can Odd-Ratios Mislead? British Medical Journal 316: 989-991. 1998

[10] J. Deeks. Swots Corner; what is an Odd Ratio? Bandolier, 3 (3), issue 25, 6-7. 1996

[11] J. E.M Arnold. Identifying links between Forests and Poverty. ECTF/IIED Forestry and Poverty Reduction Workshop, Edinburgh 13, June 2002.

[12] J. Falconer and J. E. M Arnold. Household Food Security and Forestry: An Analysis of Socio-Economic Issues. FAO, Italy, Pp. $12-79.1999$

[13] J. M Bland and D. G Altman."'The Odd ratio”'British Medical Journal 230, 1468. 2000

[14] J. R. Adhikari. Community- Based Natural Resources Management in Nepal with Reference to Community Forestry: A Gender Perspective. Journal of the Environment, vol.6, no. 7.pp. 20. 2001

[15] N. Renner. The Anatomy of Resources Wars. Washington, D.C.USA, World Watch Institute. Pp6-10. 2002

[16] O. Unekwu. Impact of Poverty on the Sustainability of Forests in Nigeria: Implication for Sustainable Forest and Reduction in Global Warming. Journal of sustainable development in Africa. Vol. 12, pp 20 - 25. 2010.

[17] S. Shackleton, C. Shackleton, and B. Cousins. Re-valuing the Communal Lands of Southern Africa: New understanding of rural livelihoods.ODI Natural Resource Perspectives no.62. The Overseas Development Institute, London. 2000.

[18] S.LLarinde and O.OOlasupo.Socio-Economic Importance of Fuelwood Production in Gambari Forest Reserve Area, Oyo State, Nigeria.Journal of Agriculture and Social Research (JASR).Vol11, No 1. 2011

[19] S.OJimoh and E.A. Haruna. Contributions of Non timber forest products to household food security and income around Gambari forest reserve, Oyo State, Nigeria. 2007

[20] World Bank. World Bank Development Indicators Database (URL:Http/Web.World Bank.Org/), last retrieved on May 15, 2015. Pg.460. 2009 